Research Article

\title{
Rural adolescent health: Issues, behaviors and self-reported
}

\section{awareness}

\author{
Molly Jacobs* \\ Health Sciences BLDG, Greenville, NC 27858, USA
}

\section{Abstract}

Purpose: The purpose of the study was to examine the health status of rural adolescents and young adults in the United States through a comprehensive review of detailed health information, behavior and health awareness. The disparity in health awareness between rural and non-rural residents compared and evaluated.

Methods: Rural-Urban Commuting Area (RUCA) codes were combined with respondentlevel data from the Longitudinal Survey of Adolescent to Adult Health (Add Health) to classify individuals as rural/non-rural residents. Health characteristics and perceived health awareness was tested for statistically significant differences using ANOVA. Differences in weight perception accuracy was compared for systematic differences controlling for self-selection into rural areas using a two-stage logistic selection model.

Findings: Analysis revealed that rural residents have a higher incidence of major health conditions including epilepsy, high cholesterol, high blood pressure and diabetes. Additionally, they have a higher prevalence of unhealthy behaviors including drinking and drug use. Rural residents are less likely to be insured, but more likely to be overweight or obese. While rural adolescents are more likely to mis-classify their body weight, this misclassification is a result of the higher incidence of overweight rather than the residential location.

Conclusion: The higher prevalence of chronic conditions combined with the income and education levels suggests the rural environment is a unique and potentially challenging context for adolescent health. Improving rural adolescent health will require innovative solutions appropriate for rural environments and changes in individual health literacy. Solutions must be multisectoral, engaging education, economic development, and other community perspectives to establish key drivers for health equity.

\section{Purpose}

Since 2000, the rural population has grown less than urban and suburban, resulting a in smaller share of Americans living in rural counties [1]. A lower population base has led to a lack of health facilities [2]. Marginalized rural populations are particularly vulnerable to underrepresentation and policy neglect [3]. The difficulty in accessing quality health care combined with the rising cost of health care has put rural communities at risk for poor health outcomes [4]. A lack of information on the health status and risks of adolescent youth in rural areas undermines policymakers' ability to justify budget expenditures for preventive care in rural areas. It is crucial to understand who they are and what contributes to health, chronic disease and conditions, to address the healthcare needs of rural communities.

\section{More Information}

*Address for Correspondence: Molly Jacobs, 600 Moye Blvd, Mail Stop 668, 4340E Health Sciences BLDG, Greenville, NC 27858, USA, Tel: 252-744-6182; Email: jacobsm17@ecu.edu

Submitted: 07 April 2020

Approved: 21 April 2020

Published: 22 April 2020

How to cite this article: Jacobs M. Rural adolescent health: Issues, behaviors and selfreported awareness. J Community Med Health Solut. 2020; 1: 001-017.

DOI: 10.29328/journal.jcmhs.1001001

ORCiD: orcid.org/0000-0001-5943-8507

Copyright: @ 2020 Jacobs M. This is an open access article distributed under the Creative Commons Attribution License, which permits unrestricted use, distribution, and reproduction in any medium, provided the original work is properly cited.

Check for updates

OPEN ACCESS
Despite the difficulties faced by rural residents and evidence of disparate health, no comprehensive health assessments of rural adolescents and young adults in the US in recent decades [5] This study will supplement existing literature by providing an assessment of adolescent/young adult health in the US. This study uses the National Longitudinal Study of Adolescent to Adult Health (Add Health)-a longitudinal study of adolescents in grades 7-12 during the 1994-95 school year followed into young adulthood with four in-home interviews. This unique dataset with comprehensive health, clinical and biological outcomes to focus on three dimensions of adolescent healthchronic disease, health behavior and health self-awareness-in order to provide an understanding of the health issues faced by rural adolescents and possible avenues to health solutions.

Rural adolescents, particularly among poor and minority youth, are susceptible to significant risk behaviors and 
health concerns [3]. Studies have found that alcohol and drug use, pregnancy, and sexually transmitted disease rates are higher among rural adolescents [6,7]. Lack of employment, transportation, education, health services, and health insurance are associated with living in rural areas and increase rural health vulnerability [8]. Additionally, rural adolescents with substance abuse problems face the challenges of accessing adequate treatment and recovery [8].

One of the most frequently cited indicators of rural health is the disproportionately high rates of overweight and obesity rates. Rural adolescents have 26 percent greater odds of obesity, compared to urban adolescents (Johnson \& Johnson, 2015). While most studies focus on those individual factors [3] that may contribute to obesity, but some examine associations with environmental characteristics such as food environment, physical changes, and social dynamics [10]. It is generally accepted that longer exposure to certain physical and social environments may contribute to differences in urban and rural obesity, but the mechanisms through which environmental aspects promote obesity warrants further study [11].

Rural areas suffer from a lack of physicians, specialists, nurses, and other healthcare practitioners, making it more difficult and cumbersome to obtain adequate preventative care [12]. Research estimates that an effective physician-topopulation ratio is 1:1200 (Gale \& Lambert, 2006), but the ratio is only 1:1910 in rural areas compared to $1: 1300$ in urban areas. National Rural Health Association reports that there are nearly 10 times more specialists per 100,000 urban residents compared to rural communities [13].

This study proceeds with a discussion of the data and methodology utilized, including the identification strategy and health outcomes selected, followed by a detailed outline of the primary significant differences between rural and non-rural youth and the most prevalent concerns among young adults in rural areas. Regression analysis attempts to explain some of these observed differences and most startling concerns. These ideas are then summarized with concluding remarks.

\section{Methods}

\section{Identification}

One primary explanation for variation in rural health outcomes research is the variable definition of rural. While the many definitions of the term rural seldom agree, the USDA Economic Research Service recommends that the choice of a rural definition be based on the purpose of the activity or the availability of information. This study utilizes the rural-urban commuting area (RUCA) codes which classify U.S. census tracts using measures of population density, urbanization, and daily commuting. RUCA codes are available in the data set used for this analysis. The most recent RUCA codes are based on data from the 2010 decennial census and the 2006-10 American Community Survey (ACS).
The Office of Management and Budget (OMB) uses RUCA codes to identify counties as metropolitan, micropolitan or neither. A metropolitan area contains a core urban area of 50,000 or more population while a micropolitan area contains an urban core of at least 10,000, but less than 50,000. All counties not part of a Metropolitan Statistical Area (MSA) are considered rural. Micropolitan counties are considered nonmetropolitan or rural along with all counties not classified as metro or micro. After the 2010 Census, the non-metro counties contained 46.2 million people-15 percent of the US population and 72 percent of the land area of the country. This included all census tracts inside metropolitan counties with the codes 4-10 to be rural. Based on this assessment and review, this study classified respondents in areas with RUCA codes of 4-10 as rural aligning with $\mathrm{OMB}$ recommendations.

\section{Data}

Add Health Wave III data was collected when respondents were between 18 and 26 years old. Biological specimens, urine and saliva samples, were obtained from a subset of Wave III respondents for tests Chlamydia trachomatis (CT), Neisseria gonorrhoeae (GC), and other experimental STI testing. An oral mucosal transudate (OMT) specimen allowed for Human Immunodeficiency Virus Type-1 (HIV-1) testing along with other curable STDs. Saliva samples enabled DNA extraction, purification and subsequent genotyping of respondents.

In addition to biological and health outcomes data, Wave III contains information on parent-child and sibling relations, contact with friends from high school, the role of mentors and mentoring relationships, personal income, wealth and debt, civic and political participation, children and parenting, involvement with the criminal justice system, and religion and spirituality. Wave III also has extensive information on health and health related behavior including diet, physical activity, access and use of health services, sexual behavior, contraception, sexually transmitted infections, pregnancy and childbearing, suicidal intentions and thoughts, mental health and depression, substance use and abuse, injury, delinquency, and violence in addition to physical measurements of height and weight. Mean values for biological, demographic, social and behavioral characteristics are given in table 1 .

\section{Covariates-health related behaviors}

A variety of behavioral patterns are included in the Add Health survey. As with all surveys, patterns of omission, valid skip, non-response and refusal can impact the robustness of response data. In order to capture behavioral impacts on health and provide robust estimates, exercise frequency, sleep sufficiency, television watching, cigarette smoking, alcohol consumption and marijuana and illegal drug use are examined. Illegal drugs include sedatives, tranquilizers, stimulants, pain killers and steroids used by respondents anytime during the five years prior to their interview. Additionally, this study examines frequency of marijuana use in the last 12 months and last 4 weeks. 
Table 1:

\begin{tabular}{|c|c|c|c|c|c|c|}
\hline \multicolumn{7}{|c|}{ Covariate Descriptive Statistics } \\
\hline & \multicolumn{3}{|c|}{ Non-Rural } & \multicolumn{3}{|c|}{ Rural } \\
\hline & 12875 & & & 1183 & & \\
\hline & $\mathbf{N}$ & Mean & Std Error & $\mathbf{N}$ & Mean & Std Error \\
\hline \multicolumn{7}{|c|}{ Race/Ethnicity } \\
\hline White & 6556 & 64.5822 & 3.0101 & 790 & 75.5688 & 5.611 \\
\hline Black & 2487 & 14.6194 & 2.0185 & 316 & 19.2103 & 5.1117 \\
\hline Hispanic & 1028 & 5.5378 & 0.8731 & 11 & 0.7987 & 0.2826 \\
\hline Indian & 415 & 2.9525 & 0.4436 & 45 & 3.0867 & 0.8599 \\
\hline Asian & 1117 & 4.5415 & 0.9181 & 8 & 0.3829 & 0.2047 \\
\hline Other & 1250 & 7.7666 & 1.1086 & 13 & 0.9526 & 0.3549 \\
\hline \multicolumn{7}{|c|}{ Age/Gender } \\
\hline Age & 9820 & 19.751 & 0.127978 & 948 & 19.8021 & 0.255906 \\
\hline Male & 6764 & 48.8644 & 0.6768 & 646 & 51.4848 & 1.5323 \\
\hline Female & 6099 & 51.1356 & 0.6768 & 537 & 48.5152 & 1.5323 \\
\hline \multicolumn{7}{|c|}{ School Enrollment } \\
\hline Not Enrolled in School & 7908 & 63.1946 & 1.5119 & 896 & 74.5069 & 2.2166 \\
\hline Enrolled in School & 4941 & 36.8054 & 1.5119 & 287 & 25.4931 & 2.2166 \\
\hline \multicolumn{7}{|c|}{ Highest Grade Completed } \\
\hline 6 & 7 & 0.0441 & 0.0235 & & & \\
\hline 7 & 10 & 0.1061 & 0.0437 & & & \\
\hline 8 & 52 & 0.6961 & 0.1564 & 10 & 0.5262 & 0.2492 \\
\hline 9 & 195 & 2.1295 & 0.2659 & 27 & 2.5964 & 0.58 \\
\hline 10 & 412 & 4.2883 & 0.3771 & 70 & 6.4159 & 0.9813 \\
\hline 11 & 823 & 6.553 & 0.4106 & 121 & 10.4783 & 1.4387 \\
\hline 12 & 4108 & 32.2841 & 1.3947 & 507 & 41.8246 & 1.9295 \\
\hline 13 & 1934 & 16.0101 & 0.9409 & 159 & 12.9007 & 1.2475 \\
\hline 14 & 1951 & 14.3438 & 0.6021 & 141 & 11.6303 & 1.3514 \\
\hline 15 & 1268 & 8.7915 & 0.6251 & 75 & 6.9965 & 1.304 \\
\hline 16 & 1480 & 10.3058 & 0.9872 & 48 & 4.1176 & 1.0093 \\
\hline 17 & 371 & 2.4449 & 0.283 & 17 & 1.3358 & 0.3812 \\
\hline 18 & 123 & 0.992 & 0.153 & 3 & 0.3862 & 0.2271 \\
\hline 19 & 69 & 0.5286 & 0.083 & 2 & 0.293 & 0.2754 \\
\hline 20 & 49 & 0.377 & 0.082 & 2 & 0.335 & 0.2551 \\
\hline 21 & 8 & 0.062 & 0.0301 & & & \\
\hline 22 & 3 & 0.043 & 0.0302 & 1 & 0.1635 & 0.1676 \\
\hline Average Highest Grade Completed & 12863 & 13.1308 & 0.090942 & 1183 & 12.5578 & 0.111956 \\
\hline \multicolumn{7}{|c|}{ Household Circumstance } \\
\hline Household size & 9581 & 4.32943 & 0.033446 & 910 & 4.217 & 0.071898 \\
\hline Lives with mother & 8983 & 93.3223 & 0.4339 & 846 & 91.8895 & 1.0438 \\
\hline Lives with father & 7440 & 78.596 & 1.1292 & 664 & 75.2789 & 1.6555 \\
\hline \multicolumn{7}{|c|}{ Income Parental/Earned/Household } \\
\hline Parental Income & 9707 & $\$ 47,009$ & 1.791871 & 911 & $\$ 33,967$ & 1.725714 \\
\hline Income from earnings & 9708 & $\$ 12,941$ & 431.7947 & 816 & $\$ 11,164$ & 952.6318 \\
\hline Household income & 3059 & $\$ 62,142$ & 2348.48 & 265 & $\$ 37,641$ & 2769.819 \\
\hline \multicolumn{7}{|c|}{ Current Health Insurance Situation } \\
\hline You have no health insurance. & 2915 & 24.1231 & 0.9158 & 333 & 28.721 & 1.9823 \\
\hline You are covered by your parents' insurance. & 3413 & 27.3756 & 1.603 & 218 & 20.4388 & 2.2762 \\
\hline You are covered by your husband's or wife's insurance. & 535 & 3.8294 & 0.3502 & 95 & 8.178 & 1.3951 \\
\hline You get insurance through work. & 4196 & 30.8677 & 1.2746 & 335 & 27.6481 & 1.7675 \\
\hline You get insurance through a union. & 77 & 0.5254 & 0.0908 & 5 & 0.5697 & 0.2953 \\
\hline You get insurance through school. & 327 & 2.4399 & 0.3286 & 12 & 0.8619 & 0.2733 \\
\hline You are covered because you are active-duty military. & 198 & 1.5208 & 0.1582 & 9 & 0.5705 & 0.3031 \\
\hline You buy private insurance yourself. & 278 & 2.2642 & 0.251 & 34 & 3.3388 & 0.7702 \\
\hline You are on Medicaid. & 745 & 6.17 & 0.6812 & 126 & 8.6948 & 1.2351 \\
\hline You are covered through the Indian Health Service. & 26 & 0.2481 & 0.1708 & 2 & 0.0792 & 0.0805 \\
\hline You don't know what your health insurance coverage is. & 72 & 0.6359 & 0.113 & 9 & 0.8992 & 0.3607 \\
\hline \multicolumn{7}{|c|}{ Months Covered by Health Insurance Last Year } \\
\hline Months last year have health insurance & 12806 & 8.76413 & 0.114088 & 1173 & 8.21798 & 0.220624 \\
\hline \multicolumn{7}{|c|}{ BMI Classification } \\
\hline Underweight & 359 & 2.8528 & 0.1741 & 29 & 2.4978 & 0.6216 \\
\hline
\end{tabular}




\begin{tabular}{|c|c|c|c|c|c|c|}
\hline Normal Weight & 5418 & 43.0547 & 1.1497 & 440 & 37.8984 & 1.9113 \\
\hline Overweight & 3726 & 29.609 & 0.5067 & 312 & 26.8734 & 1.3118 \\
\hline Obese & 3081 & 24.4835 & 1.0642 & 380 & 32.7304 & 2.0066 \\
\hline \multicolumn{7}{|c|}{ Weight Perception (Self-Reported) } \\
\hline Very Underweight & 155 & 1.1956 & 0.1478 & 11 & 0.7126 & 0.2949 \\
\hline Slightly Underweight & 1437 & 11.8442 & 0.4066 & 113 & 8.9982 & 0.8284 \\
\hline Normal Weight & 6135 & 47.9518 & 0.8577 & 549 & 45.6863 & 1.9268 \\
\hline Slightly Overweight & 4294 & 33.151 & 0.6998 & 415 & 37.0928 & 2.0026 \\
\hline Very Overweight & 822 & 5.8574 & 0.4139 & 93 & 7.5101 & 0.9772 \\
\hline \multicolumn{7}{|c|}{ Weight Action (Self-Reported) } \\
\hline Lose Weight & 4349 & 32.1654 & 0.6913 & 380 & 33.722 & 1.579 \\
\hline Gain Weight & 2016 & 16.0536 & 0.6293 & 158 & 12.5693 & 1.3897 \\
\hline Stay the same weight & 1976 & 15.2615 & 0.5407 & 147 & 12.9375 & 1.3546 \\
\hline Not trying to do anything & 4500 & 36.5195 & 0.7521 & 496 & 40.7712 & 2.6214 \\
\hline \multicolumn{7}{|c|}{ General Health Status (Self-Reported) } \\
\hline Excellent & 4242 & 32.388 & 0.6393 & 379 & 31.1397 & 2.025 \\
\hline Very Good & 5238 & 41.1549 & 0.6395 & 462 & 39.7833 & 1.8905 \\
\hline Good & 2814 & 21.7971 & 0.6092 & 271 & 22.2716 & 2.0622 \\
\hline Fair & 524 & 4.2773 & 0.2955 & 63 & 6.3396 & 0.9266 \\
\hline Poor & 44 & 0.3827 & 0.0731 & 8 & 0.4658 & 0.255 \\
\hline \multicolumn{7}{|c|}{ Behavior } \\
\hline Hours television watching weekly & 12741 & 12.7835 & 0.266617 & 1170 & 13.992 & 0.805366 \\
\hline Times exercise in last week & 12833 & 5.87526 & 0.103162 & 1181 & 5.94603 & 0.30212 \\
\hline Gets enough Sleep & 193 & 73.6075 & 3.1331 & 952 & 80.5103 & 1.7397 \\
\hline Days drink in last 12 months & 9835 & 2.93523 & 0.038049 & 834 & 2.58848 & 0.07968 \\
\hline Days smoke in last month & 4027 & 24.8003 & 0.224249 & 479 & 25.5647 & 0.502792 \\
\hline \multicolumn{7}{|c|}{ Illegal Drugs } \\
\hline Taken sedative last 5 years & 12670 & 0.1139 & 0.005676 & 1162 & 0.10173 & 0.011782 \\
\hline Taken tranquilizers last 5 years & 12676 & 0.09118 & 0.005118 & 1163 & 0.08818 & 0.016073 \\
\hline Taken stimulants last 5 years & 12675 & 0.07965 & 0.004248 & 1166 & 0.0833 & 0.011478 \\
\hline Taken pain killers last 5 years & 12661 & 0.20137 & 0.007233 & 1165 & 0.18703 & 0.0146 \\
\hline Taken steroids last 5 years & 12680 & 0.0193 & 0.001919 & 1166 & 0.01495 & 0.004042 \\
\hline Used marijuana last 5 years & 12657 & 0.47693 & 0.012005 & 1166 & 0.36284 & 0.023749 \\
\hline Used marijuana 1 last year & 5702 & 0.71624 & 0.008777 & 429 & 0.69876 & 0.026699 \\
\hline Frequency used marijuana last 30 days & 3975 & 11.8377 & 0.533064 & 296 & 9.8266 & 0.96387 \\
\hline \multicolumn{7}{|c|}{ Chronic Health Conditions } \\
\hline Asthma & 2168 & 16.907 & 0.563 & 163 & 15.0583 & 1.0631 \\
\hline Cancer/Leukemia & 116 & 0.7617 & 0.1033 & 10 & 1.005 & 0.4273 \\
\hline Depression & 1328 & 11.3926 & 0.4803 & 137 & 13.4567 & 1.4405 \\
\hline Diabetes & 120 & 0.9076 & 0.1419 & 18 & 1.5876 & 0.4031 \\
\hline Epilepsy/Seizure Disorder & 160 & 1.3949 & 0.1795 & 32 & 2.4436 & 0.5154 \\
\hline High Cholesterol & 582 & 4.4489 & 0.289 & 38 & 3.2651 & 0.5594 \\
\hline High Blood Pressure & 677 & 5.4189 & 0.3038 & 96 & 8.4615 & 0.9888 \\
\hline STD & 12796 & 0.12535 & 0.008164 & 1174 & 0.09798 & 0.019206 \\
\hline \multicolumn{7}{|c|}{ Health Status } \\
\hline Baroreflex Sensitivity $(\mathrm{ms} / \mathrm{mmHg})$ & 11022 & 0.70035 & 0.059876 & 1039 & 0.45785 & 0.044319 \\
\hline Pulse Rate Recovery (beats/min) & 11022 & 1.05952 & 0.055284 & 1039 & 0.82731 & 0.034677 \\
\hline SBP Recovery $(\mathrm{mmHg})$ & 11022 & -0.61804 & 0.069721 & 1039 & -0.94966 & 0.044025 \\
\hline High Sensitivity C-RCTV Protein (hsCRP)(MG/L) & 9888 & 4.68294 & 0.119603 & 969 & 5.63744 & 0.352647 \\
\hline Epstein Barr Viral Capsid Antigen (EBV)(AU/ML) & 9951 & 151.025 & 1.639873 & 973 & 150.133 & 3.466914 \\
\hline Count of Infectious/Inflammatory Diseases & 11021 & 0.45999 & 0.010425 & 1039 & 0.44052 & 0.029067 \\
\hline Count of Subclinical Symptoms & 11021 & 0.45529 & 0.010258 & 1039 & 0.46329 & 0.032034 \\
\hline Glucose (MG/DL) & 9889 & 107.27 & 0.480135 & 960 & 109.333 & 1.282897 \\
\hline Hemoglobin A1c (\%) & 10149 & 5.57889 & 0.014988 & 989 & 5.65618 & 0.050861 \\
\hline Diabetes Joint Classification & 11022 & 0.06205 & 0.004078 & 1039 & 0.07411 & 0.013395 \\
\hline Anti-Diabetic Medication Use & 11022 & 0.01266 & 0.001505 & 1039 & 0.01749 & 0.005455 \\
\hline Triglycerides Decile & 9636 & 5.58072 & 0.057281 & 936 & 5.91673 & 0.134905 \\
\hline Total Cholesterol Decile & 9852 & 5.58067 & 0.053905 & 962 & 5.54253 & 0.140337 \\
\hline HDL Cholesterol Decile & 9692 & 5.45514 & 0.057367 & 942 & 5.49539 & 0.155284 \\
\hline LDL Cholesterol Decile & 9253 & 5.58159 & 0.053302 & 893 & 5.42939 & 0.159837 \\
\hline Total Number of Medications Currently Using & 4145 & 1.86364 & 0.0309 & 429 & 1.95759 & 0.09849 \\
\hline
\end{tabular}


Alcohol consumption is measured as the number of days the respondent drank in the last 12 months, while smoking is measured as the number of days in the last month the respondents smoked. Binary indicators are added for having health insurance and receiving enough sleep, while variant terms measure the frequency of exercise and hours of television watching in an average week.

\section{Covariates-health issues/indicators}

Three measure of cardiovascular fitness are providedSystolic Blood Pressure (SBP) Recovery, Pulse Rate Recovery (PRR) and Baroreflex Recover. First, SBP recovery after exercise represents an important index of cardiovascular and autonomic nervous system response to physical stress and has been shown to be a clinical tool applied toward diagnosing cardiovascular abnormalities. Second, PRR is a pulse measurement taken immediately following intense exercise. PRR is used in some fitness tests to evaluate the heart's ability to recover from exercise and is used to evaluate the heart's ability to recover from exercise. Finally, the baroreflex acts as an effective buffer of short-term blood pressure fluctuations that accompany daily life. Studies suggest that a diminished baroreflex recovery is an independent risk factor for sudden death after myocardial infarction. In hypertensive humans and animals, the baroreflex control of heart rate is diminished.

In addition to SBP Recovery, PRR and Baroreflex recovery, thirteen additional clinical measures are reported for each respondent. These measures indicate the existence, persistence or maintenance of health issues. 1) High Sensitivity C-reactive Protein (hsCRP) is a protein that increases in the blood with inflammation and infection as well as following a heart attack, surgery, or trauma. Studies have suggested that a persistent low level of inflammation is often associated with cardiovascular disease (CVD). The hs-CRP test accurately measures low levels of CRP to identify low but persistent levels of inflammation and helps predict a person's risk of developing CVD.

The 2) Epstein Barr Viral Capsid Antigen (EBV) indicates that a person has or has had the Epstein Barr Virus. EBV is a member of the herpes virus family and one of the most common viruses to infect people around the world. According to the Centers for Disease Control and Prevention (CDC) [14] most people will contract EBV at some point. In adolescents and adults, it causes an illness called infectious mononucleosis, or mono, in about 35 to 50 percent of cases (2011). Also known as "the kissing disease," EBV is usually spread through saliva and rarely through blood or other bodily fluids.

Additionally, 3) Glucose level, 4) Hemoglobin A1c level, 5) Triglycerides Decile, 6) Total Cholesterol Decile, 7) HDL Cholesterol Decile and 8) LDL Cholesterol Decile are provided in addition to four summary measure. The first summary measure, 9) Count of Common Subclinical Symptoms numerates the sources of infection or inflammation that have the potential to confound hsCRP-based estimates of cardiovascular disease risk. High hsCRP concentrations triggered searches for non-cardiovascular (e.g. infectious or inflammatory) diseases which were counted and categorized.

The second summary measure, 10) Count of Infectious/ Inflammatory Diseases, therefore, counts and categorizes these conditions to enable investigators to control for potential confounding in hsCRP analyses. The third summary measure, 11) Diabetes Joint Classification, classifies respondents as having diabetes if they had a fasting glucose $\geq 126 \mathrm{mg} / \mathrm{dl}$, non-fasting glucose $\geq 200 \mathrm{mg} / \mathrm{dl}, \mathrm{HbA} 1 \mathrm{c} \geq 6.5 \%$, self-reported history of diabetes except during pregnancy or used anti-diabetic medication in the past four weeks. Finally, 12) Anti-Diabetic Medication Use, flags those who report using medications in the past four weeks associated with one or more of the following therapeutic classification codes: antidiabetic agents, sulfonylureas, non-sulfonylureas, insulin, alpha-glucosidase inhibitors, thiazolidinediones, meglitinides, miscellaneous antidiabetic agents, antidiabetic combinations, dipeptidyl peptidase 4 inhibitors, amylin analogs or incretin mimetics. A final indicator, 13) Total Medications Currently using, captures drug use at the time of the survey.

In addition to these clinical measures, Add Health Respondents indicate whether they have ever been diagnosed by a doctor or nurse with any of the following conditions: asthma, cancer/leukemia, depression, diabetes, epilepsy/ seizure disorder, high cholesterol, high blood pressure, bacterial vaginosis, cervicitis/ or mucopurulent cervicitis, chlamydia, genital herpes, genital warts, gonorrhea, hepatitis B, HIV/AIDS, human papilloma virus, pelvic inflammatory disease, syphilis, trichomoniasis, urethritis or vaginitis. For the purpose of this analysis, sexually transmitted diseases (STD) are collapsed into a single category indicating whether a respondent had been diagnosed with at least one STDs.

\section{Covariates-self-reported health awareness}

The CDC categorizes weight as (i) Underweight, (ii) Normal Weight, (iii) Overweight, and (iv) Obese based on their BMI level. Compared to other measure of body fatness, BMI appears to be correlated with various metabolic and disease outcomes. Despite criticisms of this generic scale, in general, BMI is an inexpensive and easy-to-perform method of screening for weight category. This analysis examines whether one's own body perception aligns with their BMI classification. Add Health respondents classify their weight status as (i) Very Underweight, (ii) Slightly Underweight, (iii) Right Weight, (iv) Slightly Overweight, and (v) Very Overweight. Assuming that these categories represent self-assessments of BMI, they are aligned with the CDC categories as outlined in table $1 \mathrm{a}$.

Given the very small proportion of the sample classified as very underweight, both underweight categories are combined into a single underweight group. Analysis will compare individual's assessment of their weight to the classification 


\begin{tabular}{|c|c|c|}
\hline \multicolumn{2}{|c|}{ Table 1a: } & \multicolumn{2}{|c|}{} \\
\hline BMI Value & CDC Category & Add Health Perception \\
\hline$<=18.49$ & Underweight & Underweight \\
\hline $18.50-24.99$ & Normal Weight & About the right weight \\
\hline $25.0-29.99$ & Overweight & Slightly Overweight \\
\hline $30.0+$ & Obese & Very Overweight \\
\hline
\end{tabular}

of their actual BMI to determine whether they systematically under, over or accurately estimate their body weight. The extent to which respondents over, under or accurately assess their weight is also examined and how mis-estimation varies by rural/urban status. These BMI classifications will also be compared to their reported intention to gain weight, lose weight, maintain weight or do nothing about their body weight, referred to as weight action. In addition to awareness of weight and necessary weight action, this study also examines individual assessment of their personal health which they classify as excellent, very good, food, fair or poor.

\section{Statistical analysis}

To accommodate the design of Add Health, statistical analysis needs to account for the sample weights, stratification and clustering. Failure to account for sampling weights affects the calculation of the point estimate while misspecification of the stratification or clustering impacts the calculation of the standard errors. Various procedures in SAS software package (SAS 9.4, Cary, NC) allow for correct estimation of variances/ standard errors from complex samples. ANOVA tests for statistically significant differences between rural and nonrural samples.

Multinomial logit models evaluate the observed differences in weight and weight classification. Misclassification was identified as over (1), under (-1) or accurate (0) relative to the actual BMI classification (measured relative to their actual weight classification) and expressed as a function of age, BMI level, gender, income, general health, rural residence and school enrollment. Since individuals choose geographic location (urban, rural, suburban, etc.), residential selfselections could bias estimates by confounding observed differences. To ensure that estimates are robust to residential selection, a two-stage estimation selection procedure similar to the framework popularized by Heckman, [15] also estimates misclassification [16]. Stage one-selection-frames a binary indicator for rural residency as a function of age, adolescent school enrollment and income. Stage two-response-contends that misclassification is a function of age, gender, BMI and general health status. BMI serves as an explanatory variable to allow for variation in misclassification along the distribution.

\section{Results}

\section{Demographic characteristics}

Results of listed in table 2. Few demographic differences between rural and non-rural residents exist. They appear to have similar age, gender, household size and household composition profiles. Respondents in both groups are equally distributed male and females, live in 3-4 person households and are between 18 and 24 years old. Surprisingly, the proportion living with their biological mother and/or father does not significantly differ, however, they do present significantly different education and income. Three income measurements-parent's income, own earned income and own household income-were examined and show statistically lower income for rural residents who also have statistically lower educational attainment and fewer individuals enrolled in school. The racial/ethnic composition of rural and nonrural populations also differ significantly. Rural populations appear to be less diverse than others consisting of over $75 \%$ whites, compared to $65 \%$ in other areas. Minorities have a smaller representation in rural areas compared to non-rural communities.

\section{Health issues/indicators}

There is a large difference in the health insurance status of the two groups. A higher percentage of rural residents have no health insurance, while less are covered by the insurance of a spouse or parent. They report that they held insurance for fewer months last year compared to non-rural young adults. While not directly related, it is likely that the lack of insurance coverage or full-year insurance coverage contributed to worse health outcomes by reducing the quantity and/or quality of care received [17]. Health disparities have also been linked to lack of preventative health services obtained [18].

One of the most unique aspects of the Add Health data is the large amount of medical diagnosis and clinical information available. Comparing diagnosis data between non-rural and rural adolescent and young adults show higher rates of asthma, epilepsy/seizure disorders, diabetes, high cholesterol, high cholesterol and high blood pressure in rural residents. Diabetes, high cholesterol and high blood pressure are known comorbidities of overweight and obesity and higher rates of excess weight among rural residents' likely attributes to the higher rates of related comorbidities [19,20]. Additionally, rural adolescents have higher triglycerides and hs-CRP indicating high levels of these fatty particles in the blood and greater risk of heart disease. Rural residents also show statistically higher rates of seizure disorders-a condition that has been growing in prevalence over the last decade, according to the CDC. Studies attributed these higher rates to the increased prevalence of untreated traumatic head injuries (Engel et. al., 2003).

SBP Recover, PRR and BRS differ between rural and nonrural residents suggesting lower relative cardiac fitness, increased tendency towards cardiovascular disease (CVD) and higher likelihood of coronary issues or disorders. While detailed medical review of these factors lies outside the scope of this paper, they can be impacted by a variety of factors including our age, medical conditions, medications, diet, and fitness level.

\section{Health related behaviors}

There is no difference in exercise frequency, sleep or hours 
Table 2:

\begin{tabular}{|c|c|c|c|}
\hline \multicolumn{4}{|c|}{ Race } \\
\hline Effect & F Value & $\mathrm{Pr}>\mathrm{F}$ & \\
\hline Rural & 5.84 & $<.0001$ & \\
\hline Parameter & Race & Estimate & Std Error \\
\hline Intercept & Black & $-1.4261^{* * *}$ & 0.2043 \\
\hline Intercept & Hispanic & $-3.5031^{\star * *}$ & 0.2242 \\
\hline Intercept & Asian/Pacific Islander & $-3.1422^{* * *}$ & 0.1879 \\
\hline Intercept & American Indian/Alaskan Native & $-3.9704^{* * *}$ & 0.3115 \\
\hline Intercept & Other & $-3.2465^{\star * \star}$ & 0.217 \\
\hline Rural & Black & -0.0565 & 0.1766 \\
\hline Rural & Hispanic & $1.0467^{* * *}$ & 0.2142 \\
\hline Rural & Asian/Pacific Islander & 0.0557 & 0.1655 \\
\hline Rural & American Indian/Alaskan Native & $1.3145^{\star \star \star}$ & 0.2922 \\
\hline Rural & Other & $1.1271^{* * *}$ & 0.2163 \\
\hline \multicolumn{4}{|c|}{ Gender } \\
\hline Effect & F Value & $\mathrm{Pr}>\mathrm{F}$ & \\
\hline Rural & 2.42 & 0.1223 & \\
\hline Parameter & Gender & Estimate & Std Err \\
\hline Intercept & Male & -0.0072 & 0.0335 \\
\hline Rural & Male & 0.0522 & 0.0336 \\
\hline \multicolumn{4}{|c|}{ Age } \\
\hline Source & Sum of Squares & Mean Square & F Value \\
\hline Model & 3464 & 3464.069 & $0.79^{* * *}$ \\
\hline Error & 47382291 & 4401.104 & \\
\hline Effect & F Value & $\operatorname{Pr}>\mathrm{F}$ & \\
\hline Model & 0.04 & 0.8458 & \\
\hline Intercept & $9295.14^{* * *}$ & $<.0001$ & \\
\hline Rural & 0.04 & 0.8458 & \\
\hline \multicolumn{4}{|c|}{ Enrolled in School } \\
\hline Effect & F Value & $\operatorname{Pr}>\mathrm{F}$ & \\
\hline Rural & $18.59^{\star \star \star}$ & $<.0001$ & \\
\hline Parameter & & Estimate & Std Error \\
\hline Intercept & Enrolled & $-0.8068^{* \star *}$ & 0.0712 \\
\hline Rural & Not Enrolled & $0.2654^{\star * *}$ & 0.0615 \\
\hline \multicolumn{4}{|c|}{ Highest Grad Completed } \\
\hline Effect & F Value & $\operatorname{Pr}>\mathrm{F}$ & \\
\hline Rural & 50.04 & $<.0001$ & \\
\hline Parameter & Highest Grade Completed & Estimate & Std Error \\
\hline Intercept & 6 & $-5.7188^{\star \star \star}$ & 0.672 \\
\hline Intercept & 7 & $-4.8401^{* * *}$ & 0.6499 \\
\hline Intercept & 8 & $1.9766^{\star \star}$ & 0.6677 \\
\hline Intercept & 9 & $3.3337^{* * *}$ & 0.6355 \\
\hline Intercept & 10 & $4.1361^{* * *}$ & 0.615 \\
\hline Intercept & 11 & $4.5934^{\star * *}$ & 0.6324 \\
\hline Intercept & 12 & $6.0828^{* * *}$ & 0.6226 \\
\hline Intercept & 13 & $5.144^{\star \star *}$ & 0.625 \\
\hline Intercept & 14 & $5.0372^{\star \star \star}$ & 0.6183 \\
\hline Intercept & 15 & $4.5383^{\star * *}$ & 0.6218 \\
\hline Intercept & 16 & $4.3527^{* \star *}$ & 0.5977 \\
\hline Intercept & 17 & $3.0705^{\star \star \star}$ & 0.6298 \\
\hline Intercept & 18 & $1.9991^{\star *}$ & 0.6813 \\
\hline Intercept & 19 & $1.5462^{*}$ & 0.7941 \\
\hline Intercept & 20 & $1.4442^{\star *}$ & 0.7082 \\
\hline Intercept & 21 & $-5.3777^{\star \star \star}$ & 0.6581 \\
\hline Rural & 6 & $5.7432^{\star \star *}$ & 0.6754 \\
\hline Rural & 7 & $5.7432^{\star \star *}$ & 0.6488 \\
\hline
\end{tabular}




\begin{tabular}{|c|c|c|c|}
\hline Rural & 8 & 0.8077 & 0.6694 \\
\hline Rural & 9 & 0.5687 & 0.6345 \\
\hline Rural & 10 & 0.4664 & 0.6265 \\
\hline Rural & 11 & 0.4332 & 0.6324 \\
\hline Rural & 12 & 0.5384 & 0.6301 \\
\hline Rural & 13 & 0.7758 & 0.6301 \\
\hline Rural & 14 & 0.7727 & 0.6257 \\
\hline Rural & 15 & 0.782 & 0.6415 \\
\hline Rural & 16 & $1.1266^{*}$ & 0.6326 \\
\hline Rural & 17 & 0.9701 & 0.6422 \\
\hline Rural & 18 & $1.1395^{*}$ & 0.6754 \\
\hline Rural & 19 & 0.9629 & 0.7894 \\
\hline Rural & 20 & 0.7269 & 0.7201 \\
\hline Rural & 21 & $5.7432^{* * *}$ & 0.6645 \\
\hline \multicolumn{4}{|c|}{ Household Size } \\
\hline Source & Sum of Squares & Mean Square & F Value \\
\hline Model & 16125 & 16125.13 & $8.86^{* * *}$ \\
\hline Error & 19112564 & 1820.94 & \\
\hline Effect & F Value & $\operatorname{Pr}>\mathrm{F}$ & \\
\hline Model & 2.21 & 0.1398 & \\
\hline Intercept & $10703^{* * *}$ & $<.0001$ & \\
\hline Rural & 2.21 & 0.1398 & \\
\hline \multicolumn{4}{|c|}{ Lives with Biological Mother in Household } \\
\hline Effect & F Value & $\mathrm{Pr}>\mathrm{F}$ & \\
\hline Rural & 1.81 & 0.1812 & \\
\hline Parameter & & Estimate & Std Error \\
\hline Intercept & & $-2.5325^{\text {***}}$ & 0.0774 \\
\hline Rural & Mother not Present & -0.1052 & 0.0782 \\
\hline \multicolumn{4}{|c|}{ Lives with Biological Father in Household } \\
\hline Effect & F Value & $\operatorname{Pr}>\mathrm{F}$ & \\
\hline Rural & $3.48^{*}$ & 0.0646 & \\
\hline Parameter & & Estimate & Std Error \\
\hline Intercept & & $-1.2067^{* * *}$ & 0.0618 \\
\hline Rural & Father not present & $-0.0932^{*}$ & 0.05 \\
\hline \multicolumn{4}{|c|}{ Parental Income } \\
\hline Source & Sum of Squares & Mean Square & F Value \\
\hline Model & $2.32 \mathrm{E}+08$ & $2.32 \mathrm{E}+08$ & $71.54^{* * *}$ \\
\hline Error & $3.45 \mathrm{E}+10$ & 3246958 & \\
\hline Effect & F Value & $\operatorname{Pr}>\mathrm{F}$ & \\
\hline Model & $29.72^{* * *}$ & $<.0001$ & \\
\hline Intercept & $971.15^{\star * *}$ & $<.0001$ & \\
\hline Rural & $29.72^{* * *}$ & $<.0001$ & \\
\hline \multicolumn{4}{|c|}{ Own Earned Income } \\
\hline Source & Sum of Squares & Mean Square & F Value \\
\hline Model & $3.88 \mathrm{E}+12$ & $3.88 \mathrm{E}+12$ & $12.06^{\star * *}$ \\
\hline Error & $3.39 \mathrm{E}+15$ & $3.22 \mathrm{E}+11$ & \\
\hline Effect & F Value & $\operatorname{Pr}>\mathrm{F}$ & \\
\hline Model & $3.44^{*}$ & 0.0658 & \\
\hline Intercept & $457.54^{\star * *}$ & $<.0001$ & \\
\hline Rural & $3.44^{*}$ & 0.0658 & \\
\hline \multicolumn{4}{|c|}{ Own Household Income } \\
\hline Source & Sum of Squares & Mean Square & F Value \\
\hline Model & $2.32 E+14$ & $2.32 E+14$ & $40.93^{* * *}$ \\
\hline Error & $1.88 \mathrm{E}+16$ & $5.66 \mathrm{E}+12$ & \\
\hline Effect & F Value & $\operatorname{Pr}>\mathrm{F}$ & \\
\hline Model & $48.25^{\star * *}$ & $<.0001$ & \\
\hline
\end{tabular}




\begin{tabular}{|c|c|c|c|}
\hline Intercept & $737.27^{\star \star \star}$ & $<.0001$ & \\
\hline Rural & $48.25^{\star * *}$ & $<.0001$ & \\
\hline \multicolumn{4}{|c|}{ Current Health Insurance Situation } \\
\hline Effect & F Value & $\operatorname{Pr}>\mathrm{F}$ & \\
\hline Rural & $5.78^{* * *}$ & $<.0001$ & \\
\hline Parameter & Current Health Insurance Situation & Estimate & Std Error \\
\hline Intercept & You have no health insurance. & $3.5277^{\star * *}$ & 0.2295 \\
\hline Intercept & You are covered by your parents' insurance. & $3.42^{* \star}$ & 0.2015 \\
\hline Intercept & You are covered by your husband's or wife's insurance. & $1.9782^{\star * *}$ & 0.2608 \\
\hline Intercept & You get insurance through work. & $3.631^{* * *}$ & 0.2303 \\
\hline Intercept & You get insurance through a union. & -0.3471 & 0.3369 \\
\hline Intercept & You get insurance through school. & $0.6281^{* *}$ & 0.264 \\
\hline Intercept & You are covered because you are active-duty military. & 0.1853 & 0.3609 \\
\hline Intercept & You buy private insurance yourself. & $1.2674^{\star \star \star}$ & 0.2283 \\
\hline Intercept & You are on Medicaid. & $2.249^{* * *}$ & 0.2354 \\
\hline Intercept & You are covered through the Indian Health Service. & $-1.7081^{* *}$ & 0.8653 \\
\hline Rural & You have no health insurance. & 0.0638 & 0.2405 \\
\hline Rural & You are covered by your parents' insurance. & 0.2963 & 0.2117 \\
\hline Rural & You are covered by your husband's or wife's insurance. & -0.2297 & 0.2551 \\
\hline Rural & You get insurance through work. & 0.2052 & 0.2384 \\
\hline Rural & You get insurance through a union. & 0.1092 & 0.3387 \\
\hline Rural & You get insurance through school. & 0.6696 & 0.2609 \\
\hline Rural & You are covered because you are active-duty military. & $0.6398^{*}$ & 0.3766 \\
\hline Rural & You buy private insurance yourself. & -0.0444 & 0.2385 \\
\hline Rural & You are on Medicaid. & -0.02 & 0.2424 \\
\hline Rural & You are covered through the Indian Health Service. & $0.7198^{* *}$ & 0.3058 \\
\hline \multicolumn{4}{|c|}{ Months Last Year with Health Insurance } \\
\hline Source & Mean Square & F Value & $\operatorname{Pr}>\mathrm{F}$ \\
\hline Model & 515404.1 & $14.16^{* * *}$ & 0.0002 \\
\hline Error & 36394.6 & & \\
\hline Effect & F Value & $\operatorname{Pr}>\mathrm{F}$ & \\
\hline Model & $4.87^{\star *}$ & 0.0291 & \\
\hline Intercept & $4561.49^{\star \star \star}$ & $<.0001$ & \\
\hline Rural & $4.87^{\star *}$ & 0.0291 & \\
\hline \multicolumn{4}{|c|}{ BMI } \\
\hline Source & Sum of Squares & Mean Square & F Value \\
\hline Model & 2857920 & 2857920 & $49.06^{* * *}$ \\
\hline Error & $7.74 \mathrm{E}+08$ & 58252 & \\
\hline Effect & F Value & $\operatorname{Pr}>\mathrm{F}$ & \\
\hline Model & $24.41^{* * *}$ & $<.0001$ & \\
\hline Intercept & $34220.7^{\star \star *}$ & $<.0001$ & \\
\hline Rural & $24.41^{* \star *}$ & $<.0001$ & \\
\hline \multicolumn{4}{|c|}{ Weight Perception } \\
\hline Effect & F Value & $\operatorname{Pr}>\mathrm{F}$ & \\
\hline Rural & $3.3^{\star *}$ & 0.0131 & \\
\hline Parameter & Weight Perception & Estimate & Std Error \\
\hline Intercept & Very Underweight & $-1.9701^{* * *}$ & 0.2204 \\
\hline Intercept & Slightly Underweight & $0.4432^{* * *}$ & 0.0897 \\
\hline Intercept & Normal Weight & $1.9544^{\star * *}$ & 0.0877 \\
\hline Intercept & Slightly Overweight & $1.6665^{\star * *}$ & 0.0821 \\
\hline Rural & Very Underweight & $0.3811^{*}$ & 0.2131 \\
\hline Rural & Slightly Underweight & $0.2623^{* * *}$ & 0.0857 \\
\hline Rural & Normal Weight & $0.149^{*}$ & 0.0859 \\
\hline Rural & Slightly Overweight & 0.0695 & 0.0823 \\
\hline \multicolumn{4}{|c|}{ Weight Action } \\
\hline Effect & F Value & $\operatorname{Pr}>\mathrm{F}$ & \\
\hline Rural & $3.68^{* \star *}$ & 0.0139 & \\
\hline
\end{tabular}




\begin{tabular}{|c|c|c|c|}
\hline Parameter & Weight Action & Estimate & Std Error \\
\hline Intercept & Lose Weight & $-0.1573^{* *}$ & 0.0561 \\
\hline Intercept & Gain Weight & $-0.9996^{* * *}$ & 0.0834 \\
\hline Intercept & Stay the Same Weight & $-1.0107^{* * *}$ & 0.0791 \\
\hline Rural & Lose Weight & 0.0326 & 0.0546 \\
\hline Rural & Gain Weight & $0.177^{\star *}$ & 0.0783 \\
\hline Rural & Stay the Same Weight & $0.1371^{*}$ & 0.0748 \\
\hline \multicolumn{4}{|c|}{ General Health Assessment } \\
\hline Effect & F Value & $\operatorname{Pr}>\mathrm{F}$ & \\
\hline Rural & 1.62 & 0.1739 & \\
\hline Parameter & General Health Assessment & Estimate & Std Error \\
\hline Intercept & Excellent & $4.3212^{* * *}$ & 0.2905 \\
\hline Intercept & Very Good & $4.5631^{* * *}$ & 0.288 \\
\hline Intercept & Good & $3.9559^{* * *}$ & 0.287 \\
\hline Intercept & Fair & $2.5152^{* * *}$ & 0.3054 \\
\hline Rural & Excellent & 0.1186 & 0.3006 \\
\hline Rural & Very Good & 0.1155 & 0.2936 \\
\hline Rural & Good & 0.0885 & 0.2971 \\
\hline Rural & Fair & -0.0957 & 0.3109 \\
\hline \multicolumn{4}{|c|}{ Exercise Frequency } \\
\hline Source & Sum of Squares & Mean Square & F Value \\
\hline Model & 7595 & 7595 & 0.13 \\
\hline Error & $8.27 \mathrm{E}+08$ & 58982.97 & \\
\hline Effect & F Value & $\operatorname{Pr}>\mathrm{F}$ & \\
\hline Model & 0.04 & 0.8334 & \\
\hline Intercept & $1297.9^{\star \star \star}$ & $<.0001$ & \\
\hline Rural & 0.04 & 0.8334 & \\
\hline \multicolumn{4}{|c|}{ Hours of Television Viewing } \\
\hline Source & Sum of Squares & Mean Square & F Value \\
\hline Model & 2483681 & 2483681 & $9.06^{\star * *}$ \\
\hline Error & $3.81 \mathrm{E}+09$ & 274040 & \\
\hline Effect & F Value & $\operatorname{Pr}>\mathrm{F}$ & \\
\hline Model & 2.04 & 0.1559 & \\
\hline Intercept & $965.34^{* \star *}$ & $<.0001$ & \\
\hline Rural & 2.04 & 0.1559 & \\
\hline \multicolumn{4}{|c|}{ Gets Enough Sleep } \\
\hline Effect & F Value & $\operatorname{Pr}>\mathrm{F}$ & \\
\hline Rural & 0.37 & 0.542 & \\
\hline Parameter & Gets Enough Sleep & Estimate & Std Error \\
\hline Intercept & 0 & $-1.4537^{* * *}$ & 0.0625 \\
\hline Rural & 0 & -0.0352 & 0.0576 \\
\hline \multicolumn{4}{|c|}{ Frequency of Alcohol Consumption } \\
\hline Source & Sum of Squares & Mean Square & F Value \\
\hline Model & 152432 & 152432 & $45.97^{* * *}$ \\
\hline Error & 35381341 & 3315.7 & \\
\hline Effect & F Value & $\operatorname{Pr}>\mathrm{F}$ & \\
\hline Model & $16.79^{* * *}$ & $<.0001$ & \\
\hline Intercept & $3645.13^{\star * *}$ & $<.0001$ & \\
\hline Rural & $16.79^{* * *}$ & $<.0001$ & \\
\hline \multicolumn{4}{|c|}{ Cigarette Smoking Frequency } \\
\hline Source & Sum of Squares & Mean Square & F Value \\
\hline Model & 416658 & 416658.5 & $2.85^{\star \star \star}$ \\
\hline Error & $6.60 \mathrm{E}+08$ & 146408.9 & \\
\hline Effect & F Value & $\operatorname{Pr}>\mathrm{F}$ & \\
\hline Model & 2.04 & 0.1556 & \\
\hline Intercept & $8126.33^{* * *}$ & $<.0001$ & \\
\hline
\end{tabular}




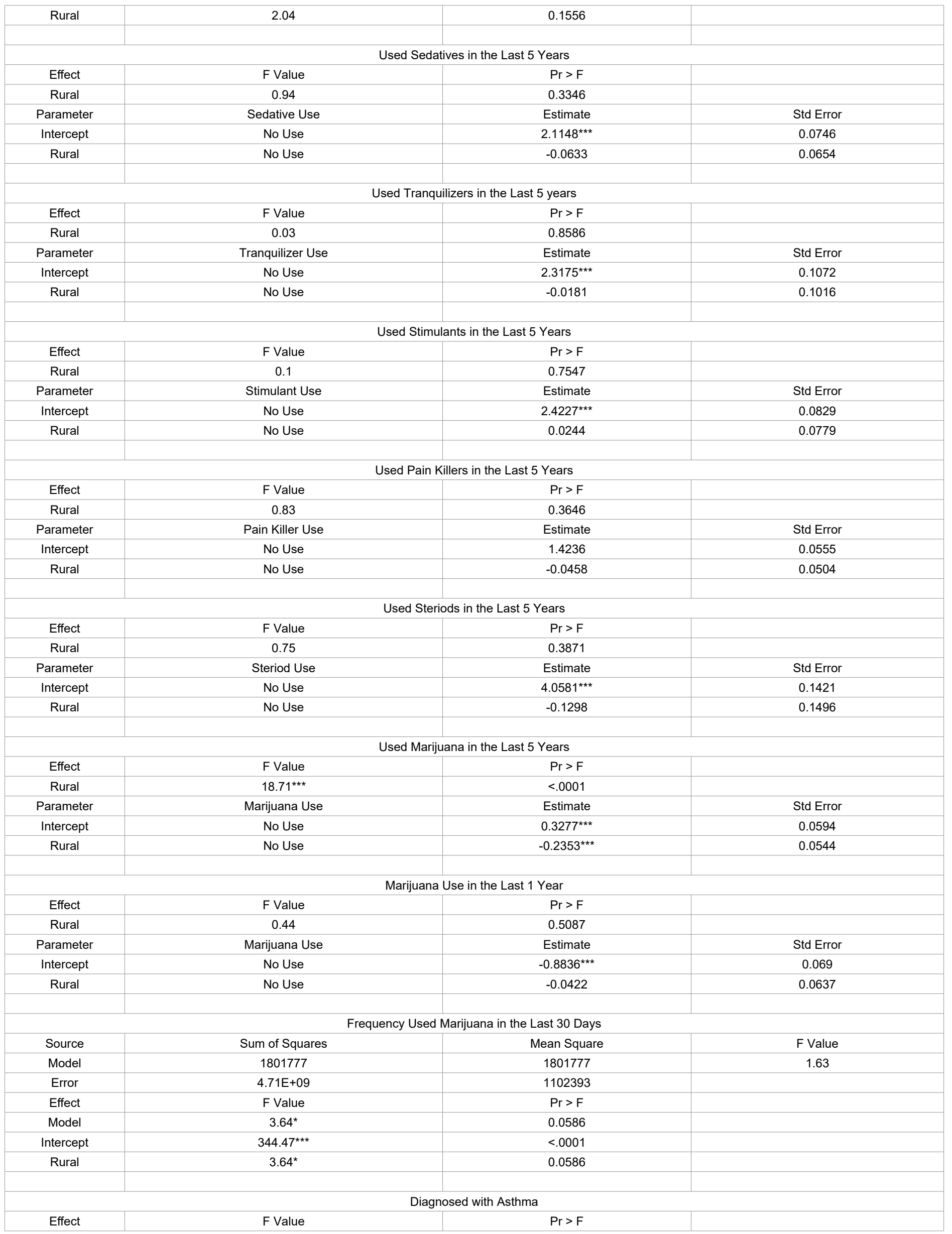




\begin{tabular}{|c|c|c|c|}
\hline Rural & 2.1 & 0.1498 & \\
\hline Parameter & Asthma & Estimate & Std Error \\
\hline Intercept & Not Diagnosed & $1.662^{* * *}$ & 0.0451 \\
\hline Rural & Not Diagnosed & $-0.068^{\star *}$ & 0.0469 \\
\hline \multicolumn{4}{|c|}{ Diagnosed with Cancer/Leukemia } \\
\hline Effect & F Value & $\operatorname{Pr}>\mathrm{F}$ & \\
\hline Rural & 0.36 & 0.5506 & \\
\hline Parameter & Cancer/Leukemia & Estimate & Std Error \\
\hline Intercept & Not Diagnosed & $4.7304^{* * *}$ & 0.2151 \\
\hline Rural & Not Diagnosed & 0.1408 & 0.2353 \\
\hline \multicolumn{4}{|c|}{ Diagnosed with Depression } \\
\hline Effect & F Value & $\operatorname{Pr}>\mathrm{F}$ & \\
\hline Rural & 2.3 & 0.1321 & \\
\hline Parameter & Depression & Estimate & Std Error \\
\hline Intercept & Not Diagnosed & $1.9567^{\star * *}$ & 0.0694 \\
\hline Rural & Not Diagnosed & 0.0956 & 0.0631 \\
\hline \multicolumn{4}{|c|}{ Diagnosed with Diabetes } \\
\hline Effect & F Value & $\operatorname{Pr}>\mathrm{F}$ & \\
\hline Rural & $3.83^{* *}$ & 0.0525 & \\
\hline Parameter & Diabetes & Estimate & Std Error \\
\hline Intercept & Not Diagnosed & $4.4107^{* * *}$ & 0.1565 \\
\hline Rural & Not Diagnosed & $0.2838^{* *}$ & 0.145 \\
\hline \multicolumn{4}{|c|}{ Diagnosed with Epilepsy/Seizure Disorder } \\
\hline Effect & F Value & $\operatorname{Pr}>\mathrm{F}$ & \\
\hline Rural & $5.46^{\star *}$ & 0.021 & \\
\hline Parameter & Epilepsy/Seizure Disorder & Estimate & Std Error \\
\hline Intercept & Not Diagnosed & $3.9734^{\star * *}$ & 0.1295 \\
\hline Rural & Not Diagnosed & $0.2865^{\star *}$ & 0.1226 \\
\hline \multicolumn{4}{|c|}{ Diagnosed with High Cholesterol } \\
\hline Effect & F Value & $\operatorname{Pr}>\mathrm{F}$ & \\
\hline Rural & $3.12^{*}$ & 0.0799 & \\
\hline Parameter & High Cholesterol & Estimate & Std Error \\
\hline Intercept & Not Diagnosed & $3.2283^{* * *}$ & 0.099 \\
\hline Rural & Not Diagnosed & $-0.1597^{*}$ & 0.0905 \\
\hline \multicolumn{4}{|c|}{ Diagnosed with High Blood Pressure } \\
\hline Effect & F Value & $\operatorname{Pr}>F$ & \\
\hline Rural & $11.66^{* * *}$ & 0.0009 & \\
\hline Parameter & High Blood Pressure & Estimate & Std Error \\
\hline Intercept & Not Diagnosed & $2.6212^{\star \star *}$ & 0.0705 \\
\hline Rural & Not Diagnosed & $0.24^{* * *}$ & 0.0703 \\
\hline \multicolumn{4}{|c|}{ Number of STD Diagnoses } \\
\hline Source & Sum of Squares & Mean Square & F Value \\
\hline Model & 1293 & 1292.614 & 2.06 \\
\hline Error & 8767058 & 627.114 & \\
\hline Effect & F Value & $\operatorname{Pr}>\mathrm{F}$ & \\
\hline Model & 1.73 & 0.1905 & \\
\hline Intercept & $113.05^{\star \star *}$ & $<.0001$ & \\
\hline Rural & 1.73 & 0.1905 & \\
\hline \multicolumn{4}{|c|}{ Baroreflex Sensitivity (ms/mmHg) } \\
\hline Source & Sum of Squares & Mean Square & F Value \\
\hline Model & 91940 & 91940.03 & $14.02^{* * *}$ \\
\hline Error & 79087053 & 6558.34 & \\
\hline Effect & F Value & $\operatorname{Pr}>\mathrm{F}$ & \\
\hline Model & $10.54^{* * *}$ & 0.0015 & \\
\hline
\end{tabular}




\begin{tabular}{|c|c|c|c|}
\hline Intercept & $241.58^{* * \star}$ & $<.0001$ & \\
\hline Rural & $10.54^{* * *}$ & 0.0015 & \\
\hline \multicolumn{4}{|c|}{ Pulse Rate Recovery (beats/min) } \\
\hline Source & Sum of Squares & Mean Square & F Value \\
\hline Model & 84299 & 84298.78 & $15.09^{* * *}$ \\
\hline Error & 67348012 & 5584.88 & \\
\hline Effect & F Value & $\operatorname{Pr}>\mathrm{F}$ & \\
\hline Model & $12.45^{\text {***}}$ & 0.0006 & \\
\hline Intercept & $849.5^{\star * *}$ & $<.0001$ & \\
\hline Rural & $12.45^{\star * *}$ & 0.0006 & \\
\hline \multicolumn{4}{|c|}{ Systolic Blood Pressure Recovery (mmHg) } \\
\hline Source & Sum of Squares & Mean Square & F Value \\
\hline Model & 171923 & 171923.2 & $19.53^{* * *}$ \\
\hline Error & $1.06 \mathrm{E}+08$ & 8804.6 & \\
\hline Effect & F Value & $\operatorname{Pr}>\mathrm{F}$ & \\
\hline Model & $16.46^{* * *}$ & $<.0001$ & \\
\hline Intercept & $353.76^{* * *}$ & $<.0001$ & \\
\hline Rural & $16.46^{\star \star \star}$ & $<.0001$ & \\
\hline \multicolumn{4}{|c|}{ High Sensitivity C-RCTV Protein (hsCRP)(MG/L) } \\
\hline Source & Sum of Squares & Mean Square & F Value \\
\hline Model & 1318239 & 1318239 & $12.27^{* * *}$ \\
\hline Error & 1.17E+09 & 107410 & \\
\hline Effect & F Value & $\operatorname{Pr}>\mathrm{F}$ & \\
\hline Model & $6.87^{\star \star \star}$ & 0.0098 & \\
\hline Intercept & $727.41^{* \star \star}$ & $<.0001$ & \\
\hline Rural & $6.87^{* * *}$ & 0.0098 & \\
\hline \multicolumn{4}{|c|}{ Epstein Barr Viral Capsid Antigen (EBV)(AU/ML) } \\
\hline Source & Sum of Squares & Mean Square & F Value \\
\hline Model & 1156102 & 1156102 & 0.07 \\
\hline Error & $1.72 \mathrm{E}+11$ & 15717576 & \\
\hline Effect & F Value & $\operatorname{Pr}>\mathrm{F}$ & \\
\hline Model & 0.05 & 0.8163 & \\
\hline Intercept & $6086.19^{* * *}$ & $<.0001$ & \\
\hline Rural & 0.05 & 0.8163 & \\
\hline \multicolumn{4}{|c|}{ Count of Infectious/Inflammatory Diseases } \\
\hline Source & Sum of Squares & Mean Square & F Value \\
\hline Model & 593 & 592.9066 & 0.83 \\
\hline Error & 8600782 & 713.2843 & \\
\hline Effect & F Value & $\operatorname{Pr}>\mathrm{F}$ & \\
\hline Model & 0.43 & 0.5154 & \\
\hline Intercept & $808.51^{* * *}$ & $<.0001$ & \\
\hline Rural & 0.43 & 0.5154 & \\
\hline \multicolumn{4}{|c|}{ Count of Subclinical Symptoms } \\
\hline Source & Sum of Squares & Mean Square & F Value \\
\hline Model & 100 & 100.1764 & 0.12 \\
\hline Error & 10104300 & 837.9748 & \\
\hline Effect & F Value & $\operatorname{Pr}>\mathrm{F}$ & \\
\hline Model & 0.06 & 0.8109 & \\
\hline Intercept & $744.41^{* \star *}$ & $<.0001$ & \\
\hline Rural & 0.06 & 0.8109 & \\
\hline \multicolumn{4}{|c|}{ Glucose (MG/DL) } \\
\hline Source & Sum of Squares & Mean Square & F Value \\
\hline Model & 6112566 & 6112566 & $4^{\star \star}$ \\
\hline Error & $1.66 \mathrm{E}+10$ & 1529982 & \\
\hline Effect & F Value & $\operatorname{Pr}>\mathrm{F}$ & \\
\hline
\end{tabular}




\begin{tabular}{|c|c|c|c|}
\hline Model & 2.31 & 0.131 & \\
\hline Intercept & $24898.9^{\star \star *}$ & $<.0001$ & \\
\hline Rural & 2.31 & 0.131 & \\
\hline \multicolumn{4}{|c|}{ Hemoglobin A1c (\%) } \\
\hline Source & Sum of Squares & Mean Square & F Value \\
\hline Model & 8851 & 8851.242 & $8.8^{* * *}$ \\
\hline Error & 11205436 & 1006.235 & \\
\hline Effect & F Value & $\operatorname{Pr}>\mathrm{F}$ & \\
\hline Model & 2.19 & 0.1416 & \\
\hline Intercept & $43154.4^{* * *}$ & $<.0001$ & \\
\hline Rural & 2.19 & 0.1416 & \\
\hline \multicolumn{4}{|c|}{ Diabetes Joint Classification } \\
\hline Source & Sum of Squares & Mean Square & F Value \\
\hline Model & 228 & 227.5605 & 2.49 \\
\hline Error & 1101430 & 91.3368 & \\
\hline Effect & F Value & $\operatorname{Pr}>\mathrm{F}$ & \\
\hline Model & 0.82 & 0.3681 & \\
\hline Intercept & $86.56^{\star \star \star}$ & $<.0001$ & \\
\hline Rural & 0.82 & 0.3681 & \\
\hline \multicolumn{4}{|c|}{ Anti-Diabetic Medication Use } \\
\hline Source & Sum of Squares & Mean Square & F Value \\
\hline Model & 36.5 & 36.51253 & 1.83 \\
\hline Error & 240789.2 & 19.96759 & \\
\hline Effect & $\operatorname{Pr}>\mathrm{F}$ & & \\
\hline Model & 0.73 & 0.3931 & \\
\hline Intercept & $28.49^{\star \star *}$ & $<.0001$ & \\
\hline Rural & 0.73 & 0.3931 & \\
\hline \multicolumn{4}{|c|}{ Triglycerides Decile } \\
\hline Source & Sum of Squares & Mean Square & F Value \\
\hline Model & 158263 & 158263 & $12.61^{* *}$ \\
\hline Error & $1.33 \mathrm{E}+08$ & 12552.3 & \\
\hline Effect & F Value & $\operatorname{Pr}>\mathrm{F}$ & \\
\hline Model & $5.64^{* *}$ & 0.019 & \\
\hline Intercept & $5698.14^{* * *}$ & $<.0001$ & \\
\hline Rural & $5.64^{* *}$ & 0.019 & \\
\hline \multicolumn{4}{|c|}{ Total Cholesterol Decile } \\
\hline Source & Sum of Squares & Mean Square & F Value \\
\hline Model & 2094.6 & 2094.6 & 0.16 \\
\hline Error & $1.38 \mathrm{E}+08$ & 12800.42 & \\
\hline Effect & F Value & $\operatorname{Pr}>\mathrm{F}$ & \\
\hline Model & 0.07 & 0.792 & \\
\hline Intercept & $5041.99^{\star \star *}$ & $<.0001$ & \\
\hline Rural & 0.07 & 0.792 & \\
\hline \multicolumn{4}{|c|}{ HDL Cholesterol Decile } \\
\hline Source & Sum of Squares & Mean Square & F Value \\
\hline Model & 2286.9 & 2286.95 & 0.18 \\
\hline Error & $1.37 \mathrm{E}+08$ & 12872.31 & \\
\hline Effect & F Value & $\operatorname{Pr}>\mathrm{F}$ & \\
\hline Model & 0.06 & 0.8014 & \\
\hline Intercept & $4022.53^{* * *}$ & $<.0001$ & \\
\hline Rural & 0.06 & 0.8014 & \\
\hline \multicolumn{4}{|c|}{ LDL Cholesterol Decile } \\
\hline Source & Sum of Squares & Mean Square & F Value \\
\hline Model & 30750.2 & 30750.18 & 2.41 \\
\hline Error & $1.29 \mathrm{E}+08$ & 12743.35 & \\
\hline
\end{tabular}




\begin{tabular}{|c|c|c|c|}
\hline Effect & F Value & $\operatorname{Pr}>\mathrm{F}$ & \\
\hline Model & 0.85 & 0.357 & \\
\hline Intercept & $4108.71^{* * *}$ & $<.0001$ & \\
\hline Rural & 0.85 & 0.357 & \\
\hline \multicolumn{4}{|c|}{ Total Number of Medications } \\
\hline Source & Sum of Squares & Mean Square & F Value \\
\hline Model & 5775 & 5775.357 & 1.75 \\
\hline Error & 15129349 & 3309.131 & \\
\hline Effect & F Value & $\operatorname{Pr}>\mathrm{F}$ & \\
\hline Model & 0.76 & 0.3837 & \\
\hline Intercept & $1469.12^{* * *}$ & $<.0001$ & \\
\hline Rural & 0.76 & 0.3837 & \\
\hline
\end{tabular}

of television. The proportions of those who reported having used sedatives, pain killers, stimulants, tranquilizers or steroids in the last five years do not differ significantly. Rural residents consume alcohol and marijuana more frequently. These trends are supported by literature showing large differences were exhibited in marijuana use, both across nonmetropolitan-metropolitan status and across youth from metropolitan and nonmetropolitan counties, but that rates of illicit drug use were essentially the same regardless of location $[21,22]$.

\section{Self-reported health awareness}

Many of these health conditions are the result of excess body weight or obesity. Examination of BMI showed higher BMI among rural youth. While these BMI levels are highly unhealthy, it does not appear that rural respondents are aware of their situation or report an intention to change. Roughly equal proportions of both rural and non-rural residents report that they are overweight, despite a greater prevalence of overweight and obesity among rural residents. This indicates that either rural respondents are not aware of their BMI status or refuse to report themselves as such. Furthermore, they do not appear to be any more likely to report wanting to lose weight than their non-rural counterparts.

Finally, given the results presented above, rural and urban residents report similar self-assessments of their overall health. This lack of health awareness among rural residents has been found by other researchers as well [23]. The lack of awareness or refusal to accept their status is often perpetuated by the community at large and ignorance regarding the detrimental health effects of excess weight [24].

\section{Misclassification selection model}

Multinomial logit model estimates of weight misclassification show that misclassification type varies by age, gender, school enrollment, and general health status, but not by income or rural residency (Table 3). As individuals age and increase BMI they are less likely to underestimate and more likely to overestimate their weight. As adolescents leave school and experience health declines more likely to overestimate and less likely to underestimate their body weight. Blacks and females tend to overestimate weight. The multinomial showed that misclassification does not differ significantly for rural and non-rural residents when controlling for age, BMI, gender and other factors.

Multinomial odds ratio estimates suggest that BMI is the largest and most important driver of weight misclassification. Estimates suggest that the probability of overestimation increases as BMI increases with an odds ratio of 36.054. Estimates suggest that BMI is the primary driver of misclassification. A two-stage sample selection model tests the robustness of these results. This technique controls for self-selection into rural areas before estimating the misclassification model. Two-stage estimates (Table 4) suggest that those factors associated with weight misclassification are similar for rural and non-rural residents. Controlling for residential self-selection, model results show that BMI is the primary determinant of misclassification and misclassification type.

\section{Conclusion}

While demographically similar, rural and non-rural youth have vastly different health profiles, behaviors and self-awareness. This study utilizes RUCA codes to classify adolescents as rural based on the OMB county classifications. Adolescents within these non-metropolitan, rural areas have higher incidence of all major health conditions including epilepsy, high cholesterol, diabetes and high blood pressure. Not only are these health concern more prevalent among rural individuals, but their health concerns extend beyond measurable conditions to include a higher prevalence of unhealthy behaviors including drinking and marijuana use.

Rural adolescents are more likely to be overweight or obese than urban. However, rural adolescents do not appear to be aware of the severity of their excess weight or the adverse health conditions that it causes-high cholesterol, high blood pressure and diabetes-which disproportionately impact rural youth. Disparate health outcomes could be partially attributed to the lack of preventative care. These findings that speak to the complexity of adolescent health. Rural areas have a higher prevalence of overweight compared to non-rural. Individuals in rural areas are also more likely to misclassify 
Table 3:

\begin{tabular}{|c|c|c|c|c|c|c|}
\hline \multicolumn{7}{|c|}{ Multinomial Logit Estimates of BMI Miscalculation } \\
\hline \multicolumn{3}{|c|}{ Model Fit Statistics } & \multicolumn{4}{|c|}{ Dependent Variable: Misclassification } \\
\hline Criterion & Intercept & Intercept, Covariates & \multicolumn{2}{|c|}{ Category } & Code & $\mathrm{N}$ \\
\hline $\mathrm{AIC}$ & 20746022 & 17467953 & \multicolumn{2}{|c|}{ Underestimate } & -1 & 1113 \\
\hline SC & 20746051 & 17468180 & \multicolumn{2}{|c|}{ Accurately Estimate } & 0 & 4751 \\
\hline$-2 \log L$ & 20746018 & 17467921 & \multicolumn{2}{|c|}{ Overestimate } & 1 & 2878 \\
\hline \multicolumn{4}{|c|}{ Analysis of Maximum Likelihood Estimates } & \multicolumn{3}{|c|}{ Odds Ratio Estimates } \\
\hline Parameter & Comparison & Estimate & Std Err & Estimate & \multicolumn{2}{|c|}{ 95\% Confidence Limits } \\
\hline Intercept & Underestimate & $9.6725^{\star * *}$ & 0.8929 & & & \\
\hline Intercept & Overestimate & $-12.4379^{\star \star \star}$ & 0.8528 & & & \\
\hline Age & Underestimate & $-0.0679^{\star *}$ & 0.0205 & 0.934 & 0.897 & 0.973 \\
\hline Age & Overestimate & 0.012 & 0.0124 & 1.012 & 0.987 & 1.037 \\
\hline Female & Underestimate & $-0.7809^{* * *}$ & 0.1071 & 0.458 & 0.371 & 0.566 \\
\hline Female & Overestimate & $1.1303^{\star * \star}$ & 0.0969 & 3.097 & 2.556 & 3.751 \\
\hline Health & Underestimate & $0.155^{\star *}$ & 0.0658 & 1.168 & 1.025 & 1.33 \\
\hline Health & Overestimate & $-0.1931^{\text {*** }}$ & 0.0442 & 0.824 & 0.755 & 0.9 \\
\hline IBMI & Underestimate & $-3.2074^{* * *}$ & 0.283 & 0.04 & 0.023 & 0.071 \\
\hline IBMI & Overestimate & $3.6044^{* * *}$ & 0.2524 & 36.759 & 22.301 & 60.589 \\
\hline School & Underestimate & 0.1894 & 0.1503 & 1.209 & 0.897 & 1.628 \\
\hline School & Overestimate & $-0.214^{* *}$ & 0.1086 & 0.807 & 0.651 & 1.001 \\
\hline Ilncome & Underestimate & -0.0205 & 0.0181 & 0.98 & 0.945 & 1.015 \\
\hline IIncome & Overestimate & -0.0164 & 0.0195 & 0.984 & 0.946 & 1.023 \\
\hline Black & Underestimate & $0.5646^{* * *}$ & 0.1123 & 0.74 & 0.558 & 0.982 \\
\hline Black & Overestimate & $-0.3006^{* *}$ & 0.1427 & 1.759 & 1.408 & 2.196 \\
\hline Rural & Underestimate & 0.0295 & 0.1267 & 1.03 & 0.801 & 1.324 \\
\hline Rural & Overestimate & 0.1349 & 0.0891 & 1.144 & 0.959 & 1.365 \\
\hline \multicolumn{7}{|c|}{ Reference: $0=$ Accurately Estimate Weight; Dependent Variable: Misclassification $=-1=$ Underestimate, $0=$ Accurately Estimate, $1=$ Overestimate } \\
\hline stimates are wei & ount for survey s & & & & & \\
\hline
\end{tabular}

Table 4:

\begin{tabular}{|c|c|c|c|c|c|c|}
\hline \multicolumn{7}{|c|}{2 Stage Residential Selection Model of Weight Misclassification } \\
\hline \multicolumn{3}{|c|}{ Selection: Rural=0 } & \multicolumn{4}{|c|}{ Selection: Rural=1 } \\
\hline \multicolumn{7}{|c|}{ Heckman First Stage Discrete Selection Response Profile } \\
\hline Index & Value & & Index & Value & & \\
\hline N: Non-Rural & 6114 & & N: Non-Rural & 7040 & & \\
\hline $\mathrm{N}$ : Rural & 2140 & & $\mathrm{~N}$ : Rural & 1894 & & \\
\hline Log Likelihood & -4649 & & Log Likelihood & -4566 & & \\
\hline $\mathrm{AIC}$ & 9307 & & AIC & 9142 & & \\
\hline Schwarz Criterion & 9342 & & Schwarz Criterion & 9178 & & \\
\hline Likelihood Ratio (R) & 150.2 & & Likelihood Ratio (R) & 98.185 & & \\
\hline \multicolumn{7}{|c|}{ Stage I: Parameter Estimates } \\
\hline Parameter & Estimate & Std Err & Marginal Effect & Estimate & Standard & Marginal Effect \\
\hline Intercept & $0.706606^{* * *}$ & 0.130202 & & 0.189208 & 0.129179 & \\
\hline Age & $-0.049711^{* \star *}$ & 0.004796 & -0.0090389 & $-0.03159^{* \star *}$ & 0.00479 & 0.0090389 \\
\hline Ilncome & $-0.027847^{\star \star \star}$ & 0.006366 & -0.008311 & $-0.030036^{\star \star *}$ & 0.006267 & 0.008311 \\
\hline Highest Grade & $0.053768^{\star *}$ & 0.016805 & 0.0149391 & $0.05399^{\star *}$ & 0.01686 & -0.0149391 \\
\hline School Enrollment & $-0.410627^{\star \star \star}$ & 0.043737 & -0.092755 & $-0.335219^{\star * *}$ & 0.043354 & 0.092755 \\
\hline \multicolumn{7}{|c|}{\begin{tabular}{|l|l|} 
Dependent Variable: Rural- $1=$ Rural, $0=$ Non-Rural \\
\end{tabular}} \\
\hline \multicolumn{7}{|c|}{ Heckman Second Step Model Fit Summary } \\
\hline Log Likelihood & -5239 & & & Log Likelihood & -1508 & \\
\hline $\mathrm{AIC}$ & 10493 & & & $\mathrm{AIC}$ & 3032 & \\
\hline Schwarz Criterion & 10547 & & & Schwarz Criterion & 3077 & \\
\hline \multicolumn{7}{|c|}{ Stage II: Parameter Estimates } \\
\hline Parameter & Estimate & Std. Err & Marginal Effect & Estimate & Standard & Marginal Effect \\
\hline Intercept & $-2.991752^{\star \star *}$ & 0.12232 & & $-3.408589^{* * *}$ & 0.236078 & \\
\hline Age & $0.01595^{* * *}$ & 0.002035 & 0.0231966 & $0.023197^{\star \star \star}$ & 0.003042 & 0.0159503 \\
\hline Female & $0.313844^{* * *}$ & 0.014654 & 0.3095502 & $0.30955^{\star * *}$ & 0.024843 & 0.3138435 \\
\hline |BMI & $0.952606^{\star \star *}$ & 0.035012 & 1.1461962 & $1.146196^{\star \star \star}$ & 0.056458 & 0.9526056 \\
\hline Black & $0.112400^{\star \star *}$ & 0.017956 & 0.1123999 & $0.193228^{\star * *}$ & 0.029395 & 0.1932281 \\
\hline General Health & $-0.07035^{\star * *}$ & 0.008804 & -0.0740746 & $-0.074075^{\star * *}$ & 0.015325 & -0.07035 \\
\hline Lambda & $-0.160641^{\star *}$ & 0.06013 & & $-0.380529^{* *}$ & 0.118997 & \\
\hline Sigma & $0.569997^{* \star *}$ & 0.005155 & & $0.536512^{* * *}$ & 0.008717 & \\
\hline
\end{tabular}

Reference: 0=Accurately Estimate Weight; Dependent Variable: Misclassification= $-1=$ Underestimate, $0=$ Accurately Estimate, $1=0$ verestimate

Estimates are weighted to account for survey sampling. 
their body weight. Regression analysis indicated that as BMI increases, individuals are more likely to underestimate their weight status. Results transcend self-selection into rural areas showing that BMI misclassification is primarily determined by BMI level irrespective of residential location.

These results reinforce the notion that rural areas are a unique area with distinct challenges related to health. While the most prevalent health conditions are not surprising, they are becoming more difficult to treat as the number of rural hospitals has decreased over recent decades and the number of accessible physicians has decreased. Given the lack of health infrastructure, geographic isolation, insufficient financial resources and lack of available services, conventional public health solutions would likely not be effective. In order to attain health equity, alternatives such as school-based or community driven healthcare should be explored.

While the limited access to care in rural areas is often cited as a reason for poor health, few studies have examined the differential health literacy among rural residents. Health literacy is the ability to obtain, read, understand, and use healthcare information in order to make appropriate health decisions and follow instructions for treatment. In addition to greater provision of care, programs that increase awareness of individuals health needs and proper preventative lifestyle measures could also assist in improving health in rural areas.

\section{References}

1. Parker K, Horowitz JM, Brown A, Fry R, Cohn D, et al. What Unites and Divides Urban, Suburban and Rural Communities. 2018. https:// www.pewsocialtrends.org/2018/05/22/what-unites-and-divides-urbansuburban-and-rural-communities/

2. Rechel B, Džakula A, Duran A, Fattore G, Edwards N, et al. Hospitals in rural or remote areas: An exploratory review of policies in 8 highincome countries. Health Policy. 2015; 120: 758-769.

PubMed: https://www.ncbi.nlm.nih.gov/pubmed/27312144

3. Curtis AC, Waters CM, Brindis C. Rural adolescent health: the importance of prevention services in the rural community. J Rural Health. 2011; 27: 60-71.

PubMed: https://www.ncbi.nlm.nih.gov/pubmed/21204973

4. Levine SB, Coupey SM. Adolescent substance use, sexual behavior, and metropolitan status: is 'urban' a risk factor? J Adolescent Health. 2003; 32L 350-355.

PubMed: https://www.ncbi.nlm.nih.gov/pubmed/12729984

5. Catalano RF, Fagan AA, Gavin LE, Greenberg MT, Irwin CE Jr, et al. Worldwide application of prevention science in adolescent health. Lancet. 2012; 379: 1653-1664.

PubMed: https://www.ncbi.nlm.nih.gov/pubmed/22538180

6. Eaton DK, Kann L, Kinchen S, Shanklin S, Flint KH, et al. Youth risk behavior surveillance - United States, 2011. Morbidity and Mortality Weekly Report: Surveillance Summaries. 2012; 61: 1-62. PMid: 22673000

7. Raingruber B. Contemporary health promotion in nursing practice. Burlington, MA: Jones \& Bartlett. 2016; PMid:27504500.

8. Santrock JW. A topical approach to life-span development. New York: McGraw-Hill Education. 2014.
9. Miller AS. CE FEATURE Adolescent Alcohol and Substance Abuse in Rural Areas: How Telehealth Can Provide Treatment Solutions. J Addic Nurs . 2005; 16: 107-115.

10. Salois MJ. The built environment and obesity among low-income preschool children. Health Place. 2012; 18: 520-527.

11. Akinbami LJ, Ogden CL. Childhood overweight prevalence in the United States: The impact of parent reported height and weight. Obesity. 2009; 17: 1574-1580.

PubMed: https://www.ncbi.nlm.nih.gov/pubmed/19629061

12. Rosenblatt RA, Chen FM, Lishner DM, Doesher MP. WWAMI Rural Health Center. The future of Family Medicine and Implications for Rural Primary Care Physician Supply. Grand Forks, ND. 2010.

13. Warshaw R. Health Disparities Affect Millions in Rural U.S. Communities. 2017. https://www.aamc.org/news-insights/health-disparitiesaffect-millions-rural-us-communities

14. Centers for Disease Control and Prevention. Sexually Transmitted Disease Surveillance. 2011. http://www.cdc.gov/std/stats11/adol.htm

15. Heckman JJ. Sample Selection Bias as a Specification Error. Econometrica. 1979; 47: 153-161.

16. Borjas GJ, Sueyoshi GT. A two-stage estimator for probit models with structural group effects. J Econometrics. 1994; 64: 165-182.

17. Frenzen PD. Health insurance coverage in US urban and rural areas. J Rural Health. 1993; 9: 204-214.

PubMed: https://www.ncbi.nlm.nih.gov/pubmed/10128159

18. Casey MM, Thiede Call K, Klingner JM. Are rural residents less likely to obtain recommended preventive healthcare services? Am J Prev Med. 2001; 21: 182-188.

PubMed: https://www.ncbi.nlm.nih.gov/pubmed/11567838

19. Bennett KJ, Probst JC, Pumkam C. Obesity among working age adults: the role of county-level persistent poverty in rural disparities. Health Place. 2011; 17: 1174-1181.

PubMed: https://www.ncbi.nlm.nih.gov/pubmed/21665515

20. Befort CA, Nazir N, Perri MG. Prevalence of obesity among adults from rural and urban areas of the United States: findings from NHANES (2005-2008). J Rural Health. 2012; 28: 392-397.

PubMed: https://www.ncbi.nlm.nih.gov/pubmed/23083085

21. Cronk CE, Sarvela PD. Alcohol, tobacco, and other drug use among rural/small town and urban youth: a secondary analysis of the monitoring the future data set. Ame J Public Health. 1997; 87: 760-764. PubMed: https://www.ncbi.nlm.nih.gov/pubmed/9184502

22. Donnermeyer JF, Scheer SD. An analysis of substance use among adolescents from smaller places. J Rural Health. 2001; 17: 105-113. PubMed: https://www.ncbi.nlm.nih.gov/pubmed/11573460

23. Hartley D. Rural health disparities, population health, and rural culture. Ame J Public Health. 2004; 94: 1675-1678.

PubMed: https://www.ncbi.nlm.nih.gov/pubmed/15451729

24. Jilcott SB, Laraia BA, Evenson KR, Ammerman AS. Perceptions of the community food environment and related influences on food choice among midlife women residing in rural and urban areas: a qualitative analysis. Women Health. 2009; 49: 164-180.

PubMed: https://www.ncbi.nlm.nih.gov/pubmed/19533508

25. Agency for Healthcare Research and Quality. National Healthcare Quality and Disparities Report chartbook on rural health care. Rockville, MD: Agency for Healthcare Research and Quality. Rockville, MD: AHRQ. 2017. 